\title{
Turkey at the Dawn of the 2020s: Old Challenges and New Prospects
}

\author{
By Gregory T. Papanikos*
}

Turkey is a great power as this is measured by its population and economy. The question is whether she is so great that she can play a decisive and, in many cases, antagonistic if not adversary role vis-a-vis her allies of the so-called western world. Apart from the rhetoric of the current Turkish leadership, her role is restricted by her commitment to international organization such as NATO when it comes to politico-military independence and European Union when it comes to politico-economic independence. It seems that Turkey has no other political and economic choice but to align her international ambitions with the priorities of its traditional allies of the western world even if this would require some sort of compromise. This would result from either her "free choice," or would be forced upon her by the use of soft and hard policies. The latter might include the threat of military action.

Keywords: Turkey, Middle East, great power competition, population, per capita income

\section{Introduction}

The 2020s marks the bicentennial of the beginning of the collapse of the Ottoman Empire and the centennial of the establishment of the modern secular Turkish republic. It appears that modern Turkey wants to return to what she was two hundred years ago by changing the status quo which was established one hundred years ago by creating a new version of an Ottoman empire. This is well received inside Turkey, but creates many enemies at its boarders and beyond. I think Kagan's (2021) testimony applies to modern Turkey as well: the dramas of the twentieth century resulted, “...from great powers whose aspirations exceeded their capacity."

Modern Turkey's ambitions exceed its ability to achieve them. The reason is not that Turkey is not a great power. ${ }^{1}$ On the contrary, Turkey is a great power (in

\footnotetext{
*President, Athens Institute for Education and Research (ATINER), Greece.

${ }^{1}$ I do not define a great power in political (security) terms, i.e., a great power is the one which can provide for its own security and a secondary power is the one that relies on great powers for its own security. Here, a great power is the one which has a large population and a high level of output production; high relative to the rest of the world. One way to measure is to use the top $10 \%$ of the countries in terms of production and population. Using these criteria, Turkey is a great power. On the other hand, I do not adopt the distinction made in security analysis and strategy between great and secondary countries because it is demeaning. All countries -small and large- have the potential to become the protagonists in world affairs if they make "smart" international strategic alliances (an issue not discussed in this paper). Israel is a good example of a small country in terms of area, population and economy but has succeeded much more than what her "power" would have predicted given the "power" of her enemies which include Turkey among many others.
} 
terms of total economy and overall population), but the world has many great powers -old and new- which will directly challenge Turkey's desire to "make Turkey great (an Ottoman empire) again.” On the other hand, a number of Turkey's bordering countries have entered into strategic alliances with other countries which directly or indirectly challenge Turkey's craving to become a great power again. This is the regional version of the so-called Great Power Competition (GPC). ${ }^{2}$

From an economic and demographic point of view, Turkey has the potential to become a great regional power again. After all, Turkey belongs to the group of G19 countries (G20 if the European Union is included) because of its strong economy and its large population. Of course, the two can be combined into only one variable, i.e., per capita output, but it does not capture the population size which is very important for non-economic reasons such as military power even though exceptions do exist, e.g., Israel. ${ }^{3}$

The issue of how great Turkey is, as well as how great it may become, is examined in this paper. The purpose is twofold. Firstly, using demographic and economic statistics, this paper shows that Turkey has grown into a great power during the first two decades of the twenty-first century. Secondly, these great economic and demographic achievements were confused by the Turkish authorities as the means to achieve domestic, regional and global political ends. Even though a strong economy and a large population are necessary to become a great power (again), they are, nevertheless, not sufficient. The latter requires a clear vision of what is possible to achieve given the regional and international political dynamics. ${ }^{4}$ It seems that the current political leadership in Turkey lacks such a clear vision which results in serious strategic failures in the international political arena, undermining not only its political objectives, but its economic achievements as well. At the moment, Turkey seems to be at a crossroads. Hard choices must be made. Two hard options seem to be available. Firstly, by the end of the 2020s, Turkey could become a stable regime, albeit not the great power of the past. Secondly, Turkey, once again, may become "the sick man of Europe"; returning to a status of an Ottoman empire at its peak is not an option in the foreseeable future.

This paper is organized in six sections, including this introduction. The next section examines three dilemmas which the current Turkish political leadership is facing. In the following two sections, I present the recent developments of Turkey's demographic characteristics and economic achievements respectively. In last section before the conclusion, I briefly discuss the current political, diplomatic and military challenges on which Turkey should make some hard decisions.

\footnotetext{
${ }^{2}$ This is not unique to Turkey. The United Kingdom wants to become a great power again, but the prospects are dismal as Shapiro and Witney (2021) have recently explained.

${ }^{3}$ Papanikos (2015) has examined the size of military spending as a share of GDP in the Mediterranean basin. Turkey spends a high share of its GDP (over 3\%) but Israel spends close to $10 \%$. Many other countries spend more than $3 \%$ of their GDP on military.

${ }^{4}$ Two other countries in the region -Russia and Egypt- have a larger population than Turkey. India is another country with a huge population which may act as a constraint to Turkey's ambition to become a great power again. The reason is Turkey's support for Pakistan. Also, the population issue is always used by Turkey as being a determining factor in intervening with other countries political affairs even for countries like Germany and France with huge Turkish diaspora.
} 


\section{Turkish Dilemmas}

Turkey's future depends on her own decisions. However, Turkey should take into consideration the constraints imposed by an ever-changing international order. $^{5}$ This requires a clear strategy as to deciding which way forward. The two choices are crystal clear by now; Turkey can choose an independent course of action by disentangling itself from all the fetters of international accords, or, alternatively, strengthen its relationships with its historical political (NATO) and economic (European Union) allies. Currently, Turkey follows an ambivalent strategy that aims at serving both objectives, but this is not sustainable, particularly in the current world order. ${ }^{6}$

The last hundred years have been characterized by Turkey's strong commitment to the interest of the western world. Table 1 provides the most important international commitment Turkey made since the establishment of the Turkish Republic in 1923.

Table 1. Turkey's International Commitments

\begin{tabular}{|l|c|}
\hline Year/Period & Commitment \\
\hline 1920 s & The signing of the Treaty of Lausanne. \\
\hline 1952 & Joining NATO. \\
\hline 1963 & Signing an association agreement with the European Economic \\
Community (now European Union).
\end{tabular}

\section{The Treaty of Lausanne}

The Treaty of Lausanne was the most important of the three strategic decisions; it determined the current borders of Turkey. This treaty was also signed by a number of countries: France, the United Kingdom, Italy, Japan, Greece, Romania, and Yugoslavia. This stamped the official dismantling of the Ottoman Empire and the establishment of the Republic of Turkey. If Turkey's current political strategy is the revival of the Ottoman Empire, then the Treaty of Lausanne must be changed either through negotiations, or, unilaterally, by an act of war. Of course,

\footnotetext{
${ }^{5}$ The most important recent international change is the new USA President who has made clear from the beginning that he would promote the idea of democracy on a global scale. The previous USA administration paid leap service to such issues and therefore violated democratic values in countries such as China, Russia and Turkey, all playing a secondary role. The new administration appears to think otherwise, which might become a serious threat to Turkey's ambition to become great again. I do not agree with statements that the USA has abandoned the Middle East such as, "The Biden Administration will face another important and evolving reality: The Middle East, which for the past century at least was shaped by global powers, is now in the midst of an internal transformation that makes it more resistant to attempts by those outside the region to determine political outcomes. This reality is most evident today with regional powers, caught in the throes of a Middle East in turmoil, having grown more confident and increasingly assertive in pressing their own policy preferences, even when these clash with US interests” Middle East Institute (2021, p. 6). ${ }^{6}$ Historically, Turkey was always the victim of international conditions. Her choices of the past were disastrous which cost many sacrifices including loss of land and people.
} 
Turkey can pursue the same strategy by implementing a policy of indirect interventions in the countries of the former Ottoman Empire. It appears that this subtle revival of the Ottoman Empire which appeared as a policy of having "zero problems" with its neighbours has so far failed because it resulted Turkey having "zero friends" at its borders. This strategy is impossible to be successful. Turkey is a great power but not so great as to be able to compete successfully with the other great powers in the area such as Russia, some member countries of the European Union, mainly France, and, above all, the USA. On the other hand, Turkey's European neighbours have no interest in Turkey as long as she remains a non-EU member. Similarly, the non-European countries have entered into other strategic alliances, excluding Turkey, such as the agreement of Cyprus, Egypt, Greece and Israel. Turkey has become a follower and a reactionary force and other countries seem to determine the regional agenda. Summing up, the renegotiation of the Treaty of Lausanne does not seem to be a realistic option.

NATO

Turkey seems to follow an independent military (strategic) policy which in some cases clashes with her commitment to NATO. Turkey cannot be a member of NATO and have an independent strategic policy including the use of its military force which clashes with other members of NATO. The case of France in Libya and the USA with the S400 Russian missiles are characteristic examples. Turkey must make a strategic choice; either within NATO or outside NATO. Turkey has a strong military but it cannot cope with countries such as France and the USA particularly when these countries have many allies in the region and Turkey has only enemies.

\section{The European Union}

This seems to be the most important commitment Turkey is facing today. The European Union issue determines the other two. As things stand now, there is not a single country in the European Union which wants seriously to discuss the Treaty of Lausanne. The European Union makes it clear to Turkey that the only solution to differences between neighbour and especially allied countries, is direct negotiations, and if these fail, a recourse to International Court of Justice. In a recent document of the European Commission (2021, p. 2) this is clearly stated:

The delimitation of the continental shelf and Exclusive Economic Zones should be addressed through dialogue and negotiations in good faith, in accordance with international law, including the UNCLOS, having recourse, if necessary, to the International Court of Justice. In the above context, unequivocal commitment to good neighbourly relations and to the peaceful settlement of disputes remains essential.

Apart from the good neighbour policy, Turkey's full membership to the EU depends on its internal policy as well. Before joining the EU, Turkey will be forced to democratize its society and polity as well as align its international economic and political relations to those of the EU. Turkey would have no other choice but democratize its society and follow a collaborative strategy with the EU. 
Full accession to the EU does not seem to be a strategy that can be realized in the near future, and definitely not during the current decade. On the contrary, I think that Turkey will move away from the EU by abandoning the required conditions for full membership. There are two reasons for this. First, many EU countries do not want Turkey to become a full member for various reasons, one of which is its large population -discussed in the next section- which will give Turkey a very high representation in the institutions of the EU such as the European Parliament. There are other reasons which relate to the lack of cultural and religious affinity of Turkey with the EU. Small and large countries of the EU would, however, pretend that they would welcome Turkey as full member if she meets the conditions. On the other hand, Turkey does not want to become member of the EU, although she pretends.

This hypocritical stance of the EU and Turkey can be demonstrated using the conflict over Cyprus. ${ }^{7}$ Turkey's diplomatic tackling of the Cypriot issue has been problematic. The EU member states which do not want Turkey to enter as a full member will use the Cypriot stalemate as an excuse to reject Turkey's application for full membership. What is the real issue? Turkey argues that a couple thousand Turks in Cyprus cannot leave peacefully together with 600 thousand Greek Cypriots. The history is well-known, but Turkey is politically at a disadvantage when its future within the EU is at stake. If the difference between the TurkishCypriots and the Greek-Cypriots is one of ethnicity and religion, then some EU countries may make the same arguments and say that Turkey cannot be part of the European family because of their different religion and ethnicity, pretty much as the Turkish-Cypriots cannot leave together with the Greek-Cypriots for exactly the same reasons.

\section{An Isolated Turkey}

It is quite possible that 2021 will be a critical year for Turkey during which a number of decisions to be taken will determine its economic and political future. If one reads the reports of many international organizations as well as of the international mass media and takes them at face value, then it appears that Turkey must make some harsh decisions in order to get out of its current regional and world isolation. According to the Director of the Washington-based Middle East Institute, Turkey's President has realized that he is, "very isolated in the region and that his whole anti-western, anti-US rhetoric is not working for him." Is this the case? Yes and no. The critical variable is the performance of the Turkish economy, and it looks that the Turkish economy has reached a different trajectory of economic growth in the last two decades. If the economic miracle of the Turkish economy continues for the next decades, then the government of Turkey (actually the president of Turkey) will have sufficient political power in his hand to pursue his own domestic and international political agenda. So far, despite his economic success since 2002, he has failed in all his strategic international political, military and diplomatic goals, thus forcing him to implement authoritarian domestic policies

\footnotetext{
${ }^{7}$ See Foka (2015) for a discussion of the division of Cyprus after the invasion of Turkey in 1974. On the energy issue see Papanikos (2017).
} 
to control the judiciary and the freedom of expression. These are examined later in this paper.

\section{A Strong Population}

Population plays an important role in Turkish politics and economics. ${ }^{8}$ Since the establishment of the modern Turkish Republic in 1923, population matters have been a thorny issue. After all, the beginning of the Turkish Republic was marked by huge Greek and Turkish population exchanges. Still, the population topic haunts modern politics because of the Muslim minority in Greece (Thrace) and the Greek Orthodox minority in Turkey have been one of the many sources of political bickering. This issue is further discussed by Dayığlu and Aslım (2015) from the perspective of reciprocity and minority rights. This theme is not examined here. The emphasis of this section is on the population comparisons between selected EU countries and Turkey because I consider it as the most important and critical in determining the future of an EU-Turkey relationship.

Tables 2 and 3 show Turkey's population and the populations of selected EU countries, i.e., those which have a population higher than ten million. Turkey is a very large country. Its high population growth rate has created a large youth cohort. In the beginning of the 2020s, Turkey's population became the largest population of Europe if Russia is excluded. In 2020, Turkey surpassed Germany. In the beginning of the 2010s, Turkey's population was 74 million people. In just one decade, Turkey's population increased by ten million people to 84 million, which amounts to the entire population of Greece, i.e., Turkey added one Greece to its population in one decade. On the other hand, Greece's population has decreased by half a million during the same period.

Table 3 compares the Turkish with the total population of the EU. In the beginning of this century, Turkey's population was 64 million which accounted for $15 \%$ of the total population of the EU. In just two decades this proportion increased to $19 \%$ and given the growth rate dynamics (columns 6-8 of Table 3), this proportion is expected to increase.

What are the economic and political implications of the above analysis? First, Turkey should find employment for its increasing youth population as well as providing the necessary education at all levels of education. In the last few decades many new universities have been established, mainly private universities to accommodate the higher demand from tertiary education by Turkey's youth population. Turkey needs to find jobs for these youth; educated or non-educated. ${ }^{9}$ This can be done either domestically by policies which promote economic growth at a higher rate than in the past, or internationally by allowing its youth to find jobs outside Turkey mainly in some advanced EU countries.

\footnotetext{
${ }^{8}$ Economic growth depends on human capital. The latter includes population. Bakan and Gökmen (2016), using a cointegration analysis of economic growth in Turkey and education spending, found a positive relation.

${ }^{9}$ This is not unique to Turkey. Egypt faces similar problems as these are analyzed in El Khouli (2015). Roberts (2016) has related the Arab Spring to the youth demographics of the countries in the area.
} 
Second, this higher Turkish population relative to an aged Europe becomes an important impediment to any Turkish aspiration to become a full member of the European Union. The political and economic implications for the EU will be tremendous and some countries of the EU think will be catastrophic. This is a thorny issue and I strongly believe it is the most important reason why Turkey would experience great resistance from many EU countries. The difficulty is that this true barrier to enter into the EU is not part of any official negotiation process, but this is exactly what is in the back of the mind of many EU countries which play a decisive role. Since this issue is politically incorrect to be raised, other problems will appear as being important. Turkey should take this into consideration when shaping its negotiations with the EU.

Table 2. The Population of Turkey and Selected EU Countries, 2011-2020 (000s)

\begin{tabular}{|l|c|c|c|c|c|c|c|c|c|c|}
\hline Country & $\mathbf{2 0 2 0}$ & $\mathbf{2 0 1 9}$ & $\mathbf{2 0 1 8}$ & $\mathbf{2 0 1 7}$ & $\mathbf{2 0 1 6}$ & $\mathbf{2 0 1 5}$ & $\mathbf{2 0 1 4}$ & $\mathbf{2 0 1 3}$ & $\mathbf{2 0 1 2}$ & $\mathbf{2 0 1 1}$ \\
\hline Turkey & 83,703 & 82,579 & 81,407 & 80,313 & 79,278 & 78,218 & 77,182 & 76,148 & 75,176 & 74,224 \\
\hline Germany & 83,165 & 83,093 & 82,906 & 82,657 & 82,349 & 81,687 & 80,983 & 80,646 & 80,426 & 80,275 \\
\hline France & 67,634 & 67,456 & 67,265 & 67,063 & 66,831 & 66,581 & 66,312 & 65,991 & 65,651 & 65,330 \\
\hline Italy & 60,315 & 60,339 & 60,459 & 60,537 & 60,628 & 60,731 & 60,789 & 60,646 & 60,339 & 60,060 \\
\hline Spain & 47,151 & 47,104 & 46,729 & 46,533 & 46,450 & 46,410 & 46,455 & 46,593 & 46,766 & 46,736 \\
\hline Poland & 38,358 & 38,390 & 38,413 & 38,422 & 38,427 & 38,455 & 38,484 & 38,502 & 38,534 & 38,526 \\
\hline Romania & 19,241 & 19,370 & 19,477 & 19,593 & 19,706 & 19,822 & 19,916 & 19,989 & 20,060 & 20,148 \\
\hline Netherlands & 17,433 & 17,345 & 17,232 & 17,131 & 17,030 & 16,940 & 16,865 & 16,804 & 16,755 & 16,693 \\
\hline Belgium & 11,537 & 11,486 & 11,427 & 11,375 & 11,331 & 11,274 & 11,209 & 11,159 & 11,107 & 11,038 \\
\hline Czechia & 10,707 & 10,669 & 10,626 & 10,590 & 10,565 & 10,543 & 10,525 & 10,511 & 10,509 & 10,497 \\
\hline Greece & 10,665 & 10,725 & 10,733 & 10,755 & 10,776 & 10,821 & 10,892 & 10,965 & 11,045 & 11,105 \\
\hline Sweden & 10,320 & 10,279 & 10,175 & 10,058 & 9,923 & 9,799 & 9,696 & 9,600 & 9,519 & 9,449 \\
\hline Portugal & 10,287 & 10,286 & 10,284 & 10,300 & 10,326 & 10,358 & 10,401 & 10,457 & 10,515 & 10,558 \\
\hline
\end{tabular}

Source: European Commission (2020).

Table 3. Turkish and EU Population Compared

\begin{tabular}{|c|c|c|c|c|c|c|c|c|}
\hline Year & $\begin{array}{c}\text { EU- } \\
\text { POP } \\
(000 s) \\
(1)\end{array}$ & $\begin{array}{c}\text { TUR- } \\
\text { POP } \\
\text { (000s) } \\
(2)\end{array}$ & $\begin{array}{c}\text { TUR/ } \\
\text { EU } \\
\text { POP } \\
\text { (2)/(1) } \\
\% \\
(3)\end{array}$ & $\begin{array}{c}\text { EU- } \\
\text { POP } \\
(0-14) \\
(000 s) \\
(4)\end{array}$ & $\begin{array}{l}\text { TUR- } \\
\text { POP } \\
(0-14) \\
(000 s) \\
(5)\end{array}$ & $\begin{array}{c}\text { TUR/EU } \\
\text { POP (0- } \\
14) \\
(5) /(4) \% \\
(6)\end{array}$ & $\begin{array}{c}\text { EU-POP (0- } \\
\text { 14)/ } \\
\text { EU-POP } \\
\text { (4)/(1)\% } \\
(7)\end{array}$ & $\begin{array}{c}\text { TUR-POP (0- } \\
\text { 14)/ } \\
\text { TUR-POP } \\
\text { (5)/(2)\% } \\
\text { (8) }\end{array}$ \\
\hline 2000 & 428154 & 64269 & 15.011 & NA & 18905 & NA & 16.687 & 29.415 \\
\hline 2001 & 428915 & 65166 & 15.193 & 71574 & 18906 & 26.415 & 16.507 & 29.012 \\
\hline 2002 & 429720 & 66003 & 15.360 & 70935 & 18906 & 26.653 & 16.310 & 28.644 \\
\hline 2003 & 431310 & 66795 & 15.487 & 70346 & 18907 & 26.877 & 16.115 & 28.306 \\
\hline 2004 & 432868 & 67599 & 15.617 & 69759 & 18936 & 27.145 & 15.911 & 28.012 \\
\hline 2005 & 434497 & 68435 & 15.750 & 69134 & 18964 & 27.431 & 15.738 & 27.711 \\
\hline 2006 & 435872 & 69295 & 15.898 & 68597 & 18981 & 27.670 & 15.596 & 27.392 \\
\hline 2007 & 437405 & 70158 & 16.040 & 68218 & 18990 & 27.837 & 15.487 & 27.067 \\
\hline 2008 & 438869 & 71052 & 16.190 & 67967 & 18715 & 27.536 & 15.430 & 26.341 \\
\hline 2009 & 440238 & 72039 & 16.364 & 67931 & 18824 & 27.711 & 15.416 & 26.130 \\
\hline 2010 & 440971 & 73142 & 16.587 & 67982 & 18869 & 27.756 & 15.385 & 25.798 \\
\hline 2011 & 441597 & 74224 & 16.808 & 67938 & 18883 & 27.794 & 15.334 & 25.440 \\
\hline 2012 & 442376 & 75176 & 16.994 & 67835 & 18872 & 27.820 & 15.313 & 25.104 \\
\hline 2013 & 443023 & 76148 & 17.188 & 67841 & 18853 & 27.791 & 15.294 & 24.759 \\
\hline 2014 & 443725 & 77182 & 17.394 & 67863 & 18856 & 27.786 & 15.257 & 24.431 \\
\hline 2015 & 444682 & 78218 & 17.590 & 67843 & 18874 & 27.820 & 15.229 & 24.130 \\
\hline
\end{tabular}




\begin{tabular}{|l|l|c|c|c|c|c|c|c|}
\hline 2016 & 445700 & 79278 & 17.787 & 67875 & 18906 & 27.854 & 15.212 & 23.848 \\
\hline 2017 & 446392 & 80313 & 17.992 & 67903 & 18980 & 27.951 & 15.174 & 23.632 \\
\hline 2018 & 447155 & 81407 & 18.206 & 67853 & 19109 & 28.162 & NA & 23.473 \\
\hline 2019 & 448081 & 82579 & 18.429 & NA & NA & NA & NA & NA \\
\hline 2020 & 448426 & 83703 & 18.666 & NA & NA & NA & NA & NA \\
\hline 2021 & 448821 & 84845 & 18.904 & NA & NA & NA & NA & NA \\
\hline 2022 & 449367 & 86005 & 19.139 & NA & NA & NA & NA & NA \\
\hline
\end{tabular}

Source: European Commission (2020) and Author's Calculations.

The above overall demographic analysis disguises two important issues which relate to the "ideology" of modern Turkey. It appears that Turkey emphasizes the homogeneity of its population ever since the establishment of the Turkish republic in 1923. The exchange of Greek-Turkish population was a deliberate action by both Greek and Turkish leadership at the time to create a homogeneous ethnicity. As a matter of fact, Gingeras (2016) draws an analogy between the German Nazi and Turkey under Mustafa Kemal Atatürk in interpreting history and race the same way. The Nazis failed. The current leadership in Turkey emphasizes the creation of a society that has a common history which goes back to the ancient people of Mesopotamia of Hittites with their own unique language and civilization. The history of Hittites or pro-Hittites goes back thousands of years, and if this is the case then modern Turkey can claim that they were always part of Anatolia at least since 5000 BCE. One of the first policies of the 1920s reforms was the change of language by substituting the Arab alphabet with the Latin alphabet; and finally, the issue of religion. Now, a Turkish citizen as opposed to an Ottoman citizen has the same religion. Thus, modern Turkey's leadership wants to create an ethnos which has a long history in the area, the same unique language, and the same religion. What about geography? Modern Turkey considers that all geographical areas which historically belonged to their race going back to Hittites, and more recently to the Ottoman Empire as being part of Turkey, speak the same language and share the same religion. Things become more complicated when Turkey wants to play a sort of a leader of the Muslim world by supporting, for example, the Muslim brotherhood.

Three points here are important. First, if this is part of Turkey's ideology, then sooner or later it will clash with populations which are larger than hers such as India's, Russia's and Egypt's. Second, inside Turkey there is a distinct race which has a much higher population growth than the pure Turkish population. As mentioned in Bekdil (2021), the Kurdish-speaking population has a fertility rate of 3.41 as opposed to 2.09 in the Turkish-speaking population. If this is true, then the overall population growth is the result of an increase in the Kurdish population and not of the Turkish population. This is not a blessing but a curse for the future internal stability of Turkey. My third point might be more sensitive. Since history is used to legitimize the "Turkiness" of the Turkish population, one might argue -based on strong historical evidence- that most of Turkey's population today is the result of forced ex-islamization of its non-Muslim population. A DNA test might show that there is little Turkiness left to the population of Turkey today. In this case, the whole ideological edifice of modern Turkey might collapse. However, this need not be the case. The greatest country of the world, the USA, has a large non-homogeneous population. The great cities of Istanbul and Izmir were great 
when they had a mixture of populations in terms of history, religion and languages. Population is not the problem, but the policies towards the population of different histories, languages and religions is the problem.

\section{Strong but Unstable Economic Performance}

Population is only one pillar of a great power; the other is the economy. Figure 1 shows the per capita Gross Domestic Product (GDP) in Purchasing Power Parities from 1990 in constant 2017 US Dollars and Figure 2 its rate of growth. The curve shows three trajectories of growth. The first lasted till the end of the previous century. Per capita GDP increases from 12 thousand to 16 thousand US Dollars in just a decade. However, the first two years of the current century the Turkish people experience a sharp decline. This might explain why there was a change in the political regime.

Figure 1. GDP per Capita PPP (Constant 2017 International \$)

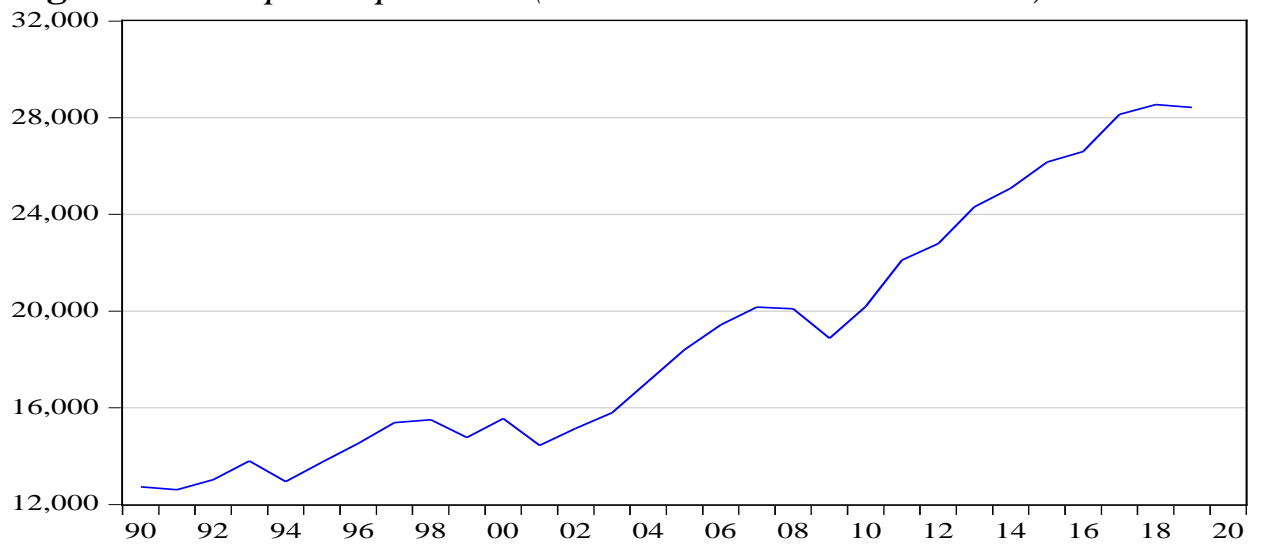

Source: World Bank and Author's Calculations.

Figure 2. GDP per Capita PPP Growth (Constant 2017 International \$)

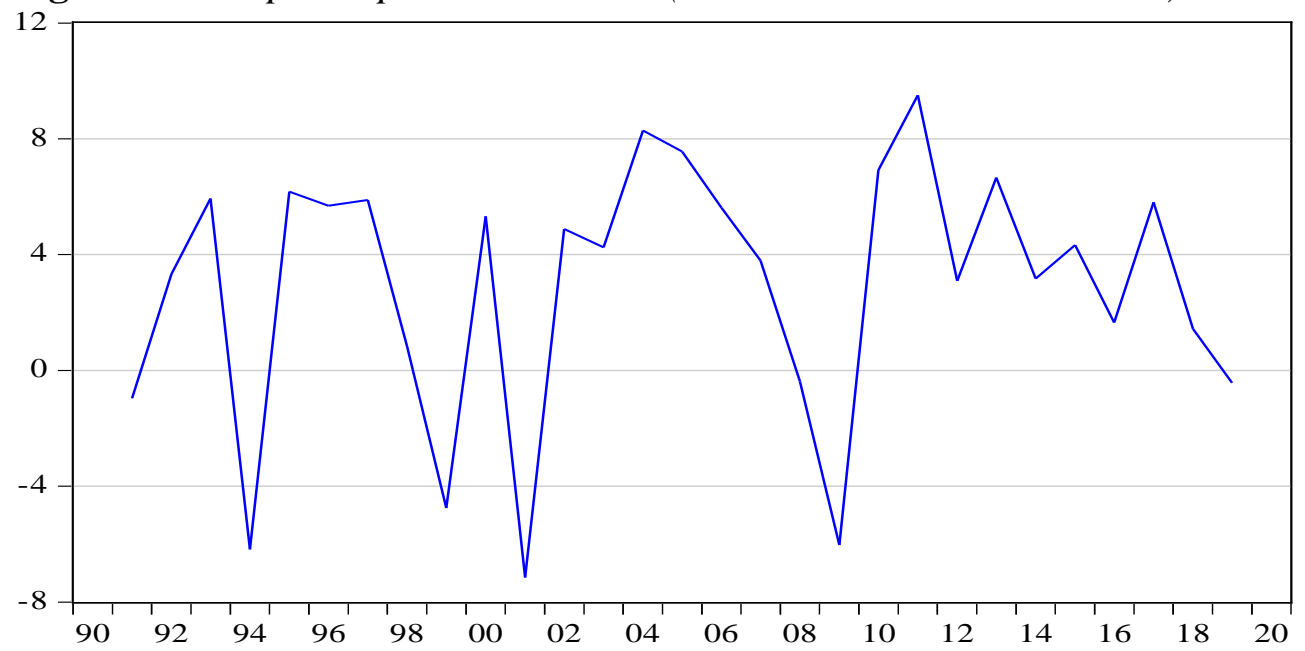

Source: World Bank and Author's Calculations. 
The second growth trajectory started right after the change in government and was characterized by a strong increase in per capita GDP from about 15 thousand in the beginning of the first decade of the current century to just over 20 thousand US Dollars at the end of the decade. The impact of the great recession which hit most of the countries between 2008-2010 was very small in Turkey. On the contrary, Turkey's economy in the second decade of the twenty-first century continued to increase at a very high rate. From 20 thousand dollars in the beginning of the second decade, it reached 28 thousand US Dollars by the end of it.

The exceptional economic performance may explain Turkish people's continuous support for the political regime. However, the two Figures show a decrease in recent years in per capita GDP, which if continued, might jeopardize the military and political international ambitions of the current political regime. It is quite possible that this reduction in economic activity will create domestic political problems, shaking the political support of the existing government. An early warning were the results of local elections in 2019 as was manifested by the double elections for the city of Istanbul.

If the bad economic situation deteriorates, then the current government can hold on to power by playing out the nationalist tune and risk international military adventures such as in Syria, Libya and Armenia-Azerbaijan which will undermine its relations with its traditional NATO allies. However, such an endeavor will receive strong political support from many Turkish people. The Turkish government may also use it to explain that the bad economic situation is due to the international economic war of "imperialists," but Turkey is independent and strong and can sacrifice economic welfare for national welfare. This rhetoric has served many governments well whose handling of the economy has been very bad. One way to deal with the economic competence is to use nationalistic rhetoric. People are willing to listen and accept it, but not for long.

Many people do not usually accept such rhetoric, and the opposition will blame the government for the bad economic situation stressing the issue of economic corruption and nepotism. In such a situation, authoritarian governments restrict civic freedoms and use the judiciary to impose their will and restrict the opposition. If this oppression is combined with the nationalist saga, as is the case of Turkey with the Kurds, then so much the better. This policy of domestic oppression is a good strategy if the regime does not expect a quick economic recovery. It seems that this is the case in Turkey in the beginning of the current -third- decade of the twenty-first century. This theme is examined in the following section.

\section{A Failing Democracy}

There are many indices which can be used to show the trajectory of Turkey's performance in achieving "democracy". I examined the indices reported by the Swedish V-Dem Institute. ${ }^{10}$ All indices show a deterioration of democracy in

\footnotetext{
${ }^{10}$ https://www.v-dem.net/en/about/about-v-dem/
} 
Turkey. I have selected two indices from a couple of hundred reports just to demonstrate the point of a failing democracy. These are reported here as Figures 3 and 4. Both measurements end in 2019 and therefore no conclusions can be drawn for the beginning of the third decade of twenty-first century.

Recently, university students have demonstrated against Turkey's president dismantling of the autonomy of Turkish universities. Figure 3 shows that this is process of infringement of academic freedom throughout the 2010s. Throughout the first decade of the current century, Turkey's performance on academic freedom was stable, but throughout the second decade the situation has worsened dramatically. In recent years the situation has become worse and many students demonstrated against the president's attempts to restrict academic freedom and self-governance of the universities.

Figure 4 measures the rule of law. The pattern is similar to the academic freedom index. The rule of law has deteriorated during the second decade of the twenty-first century and the prospects are not any better for the third decade.

It seems that Turkey has decided to become more authoritarian to meet its old challenge of domestic stability, but this will undermine her prospects in the international arena. Countries such as the USA and EU will always use these indicators to support direct or indirect sanctions against Turkey. Global democracy will be high on the agenda of the current USA administration and Turkey sooner or later should meet this challenge if she wants to change her dismal prospects.

Figure 3. Academic Freedom Index, 2000-2019 [Scale: Interval, from low to high $(0-1)]$

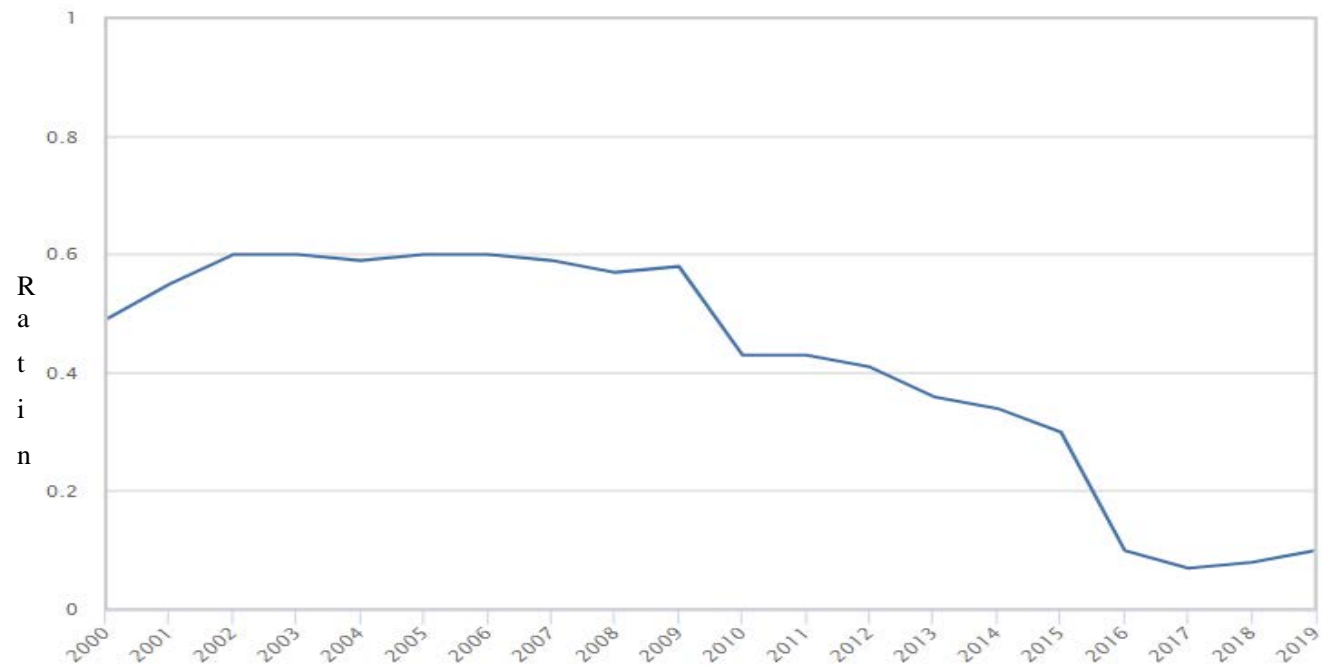

Note: This index is based on the question, "To what extent is academic freedom respected?" According to the V-Dem Institute's clarification “Academic freedom is understood as the right of academics, without constriction by prescribed doctrine, to freedom of teaching and discussion, freedom in carrying out research and disseminating and publishing the results thereof, freedom to express freely their opinion about the institution or system in which they work, freedom from institutional censorship and freedom to participate in professional or representative academic bodies (UNESCO 1997). The Academic Freedom Index is designed to provide an aggregated measure that captures the de facto realization of academic freedom, including the degree to which highereducation institutions are autonomous." 
Figure 4. Rule of Law Index, 2000-2019 [Scale: Interval, from Low to High (0-1)]

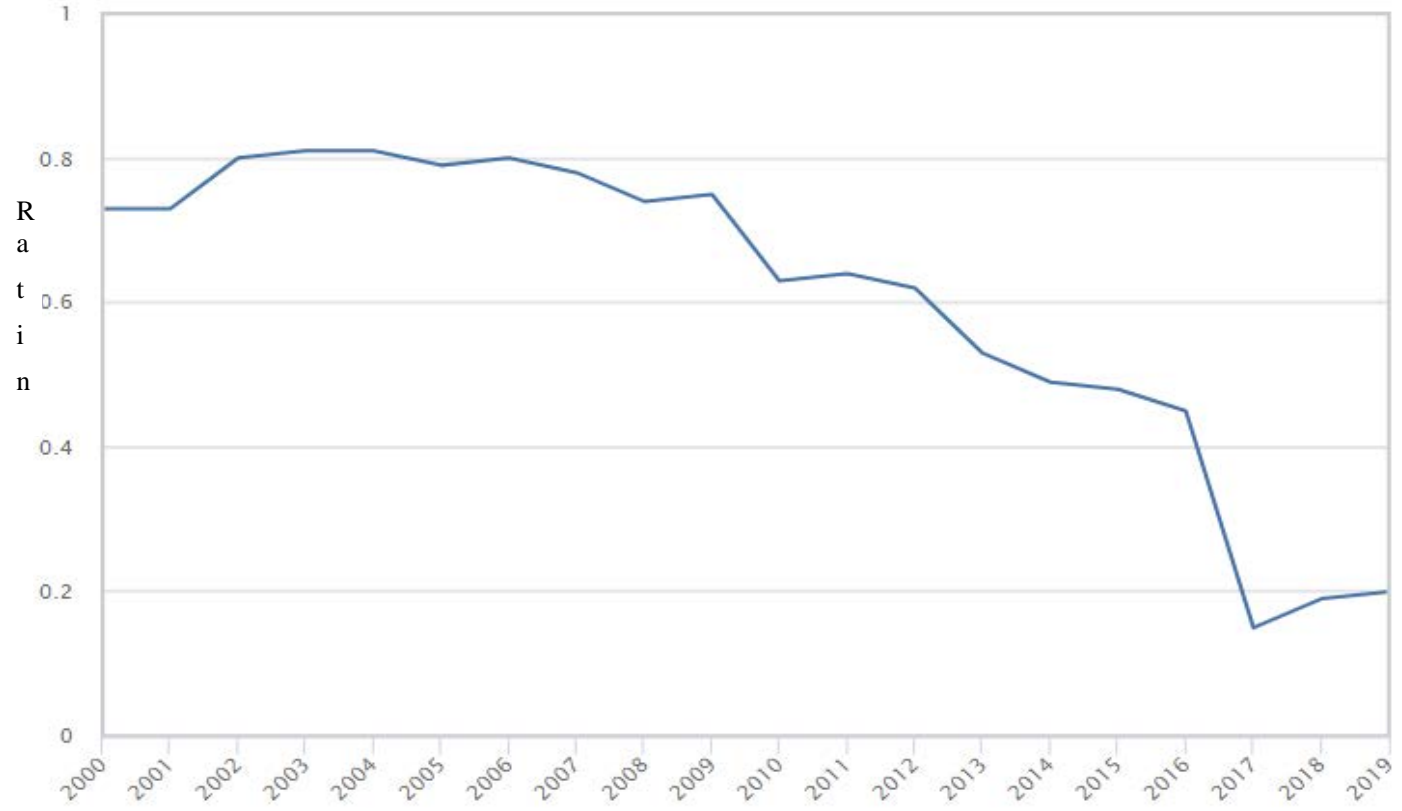

Note: This index is based on the question, "To what extent are laws transparently, independently, predictably, impartially, and equally enforced, and to what extent do the actions of government officials comply with the law?” According to the V-Dem Institute's clarification "The index is formed by taking the point estimates from a Bayesian factor analysis model of the indicators for compliance with high court (v2juhccomp), compliance with judiciary (v2jucomp), high court independence (v2juhcind), lower court independence (v2juncind), executive respects constitution (v2exrescon), rigorous and impartial public administration (v2clrspct), transparent laws with predictable enforcement (v2cltrnslw), access to justice for men (v2clacjstm), access to justice for women (v2clacjstw), judicial accountability (v2juaccnt), judicial corruption decision (v2jucorrdc), public sector corrupt exchanges (v2excrptps), public sector theft (v2exthftps), executive bribery and corrupt exchanges (v2exbribe), executive embezzlement and theft (v2exembez).”

\section{Conclusion}

Turkey should deal with its old challenges, including her full membership to the European Union. However, there are many impediments to overcome, such as the internal respect of human rights and democratic processes. It seems that these are positively correlated with economic achievements. Usually, the decline of the economy is associated with more internal authoritarian measures.

Turkey wants to become a great (world or regional) power, but the prospects are dismal. Its strong population and economy are undermined by internal structural problems. One of the characteristics of great powers is that they appear to be part of the solution to international political and military problems. So far, Turkey is part of the problem which has created great animosity in her own region, and has called for the intervention of outsiders such as the USA, Russia and France. Turkey’s old challenges (e.g., the Cyprus issue) still haunt her, undermining her great prospects (e.g., full membership to the EU and zero problems with her neighbors). As things stand now, the economic and political prospects are not 
good. Turkey, instead of having zero problems, has ended up with zero true friends.

\section{Acknowledgements}

An early draft of this paper was presented at the $14^{\text {th }}$ Annual International Conference on Mediterranean Studies, 29-30 March 2021, Athens, Greece. I would like to thank all participants and especially Defne Gönenç, Nickolas Pappas and David Wick. I am solely responsible for the many remaining errors.

\section{References}

Bakan S, Gökmen S (2016) A driving force of economic growth in Turkey: human capital. Athens Journal of Mediterranean Studies 2(1): 7-20.

Bekdil B (2021) Are the Kurds the next kingmakers in Turkey? BESA.

Dayığlu A, Aslım İ (2015) Reciprocity problem between Greece and Turkey: the case of Muslim-Turkish and Greek minorities. Athens Journal of History 1(1): 37-50.

El Khouli M (2015) The demography of employment and unemployment in Egypt from 2002 to 2012. Athens Journal of Mediterranean Studies 1(2): 121-146.

European Commission (2020) AMECO database. European Commission.

European Commission (2021) State of play of EU-Turkey political, economic and trade relations. Brussels: European Commission.

Foka Z (2015) Shared Space in Conflict Areas: Exploring the Case of Nicosia's buffer zone. Athens Journal of Mediterranean Studies 1(1): 45-60.

Gingeras R (2016) Mustafa Kemal Atatürk: heir to the Empire Oxford: Oxford University Press.

Kagan R (2021) A superpower, like it or not: why Americans must accept their global role. Foreign Affairs.

Middle East Institute (2021) The Biden Administration and the Middle East: policy recommendations for a sustainable way forward. USA: The Middle East Institute.

Papanikos GT (2015) Military spending, international trade and economic growth in the Mediterranean Basin. Athens Journal of Mediterranean Studies 1(2): 187-194.

Papanikos GT (2017) Energy security, the European Energy Union and the Mediterranean countries. Athens Journal of Mediterranean Studies 3(4): 341-354.

Roberts K (2016) The socio-demographic and political contexts and legacies of the "Arab Spring” in North Africa. Athens Journal of Mediterranean Studies 2(4): 295-314.

Shapiro J, Witney N (2021) The delusions of global Britain: London will have to get used to life as a middle power. Foreign Affairs.

UNESCO (1997) Recommendation concerning the status of higher-education teaching personnel. UNESCO. 
